Presidency of the Institute of Fuel :

Mr. J. R. Rylands

Mr. J. R. RyLands, who has recently been elected president of the Institute of Fuel and will take office in October next, served his engineering apprentice. ship with Henry Berry and Co., Ltd., of Leeds, and then, after service in the Army during the First World War, graduated from the University of Leeds. He worked at first as an electrical engineer with the Taquah and Abosso Gold Mining Co., of the Gold Coast, but later transferred to E. Green and Son, Ltd., of Wakefield, makers of fuel economizers, of which company he is now chief engineer and a director. For his work done with J. R. Jenkinson during the Second World War on fouling problems associated with economizers and air heaters, he received the John Hopkinson Premium for 1943 of the Institution of Electrical Engineers, and this work was followed by further research into the corrosion of boiler, economizer and air-heater surfaces, for which he was awarded the Thomas Lowe Gray Prize for 1948 of the Institution of Mechanical Engineers. Mr. Rylands has been active in the electrical branch of the engineering profession, having served as chairman of the North Midland Centre of the Institution of Electrical Engineers.

\section{J. A. C. Chaptal, Comte de Chanteloup (1756-} 1832)

THE distinguished chemist and statesman, Jean Antoine Claude Chaptal, who was born at Nogaret, Lozère, two hundred years ago on June 4, 1756, is to-day remembered chiefly for his contributions to the technical development of modern industry by the application of the science of chemistry, and for having coined the name for nitrogen. The son of an apothecary, he owed his education to a rich uncle, Dr. Claude Chaptal, and in 1777 he graduated M.D. at the University of Montpellier. After studying science in Paris, in 1781 he was appointed to a specially instituted chair of chemistry at Montpellier, where he taught the new doctrines of Lavoisier with eloquent lucidity. On the death of his uncle he inherited a large fortune, part of which he devoted to establishing chemical works for the manufacture of mineral acids, alum, white lead and soda. In 1797 he was made director of the saltpetre works at Grenelle by the Comité de Salut Public and greatly simplified the procedure of making gunpowder. Two years later he was created a Councillor of State by the First Consul, and in 1801 he succeeded Lucien Bonaparte as Minister of the Interior. In this capacity he founded a society of industries and a vaccine society, reorganized the hospitals, organized schools of pharmacy, introduced the metric system of weights and measures, and did much to promote the scientific culture of vines. Besides his many scientific honours, he was a grand officer of the Legion of Honour (1805), and received the title of Comte de Chanteloup (1811). On Napoleon's return from Elba in 1815 he became director-general of commerce and manufactures. His best-known writings are "Eléments de Chimie" (1790 and several editions), "Traité des Salpêtres et Goudrons" (1796) and "L'Art de faire les Eaux-de-Vie" (1819). He died in Paris on July 30, 1832, at the age of seventy-six.

\section{Joseph Pitton de Tournefort (1656-1708)}

JoSEPh PitTon DE TOURNEFoRT, who was born at Aix three hundred years ago on June 5, 1656, is remembered as a pioneer botanical systematist whose classification of groups higher than genera was accepted until the time of Linnæus. Born of a noble family, he was intended for the church, but after his father's death in 1677 he devoted himself wholeheartedly to his first love, namely, botany. He studied medicine at Montpellier and also at Paris, where in 1683 he became professor of botany at the Jardin Royal des Plantes. In 1692 he was elected to the Royal Academy of Sciences, Paris, and he received the M.D. of Paris in 1698. Two years later he was sent by the king to Spain, Portugal and Asia Minor to collect botanical material. Reviving the concept of genera and species originated by Kaspar Bauhin, he provided his genera with names and characters, adding the species and varieties without special description. He refused to accept the doctrine of sexuality in the vegetable kingdom formulated by Rudolph Jacob Camerarius, of Tübingen, in 1691-94. Inclined to be dogmatic, de Tournefort regarded the morphology of the flower and fruit as the proper basis for classification, founding his system on the form of the corolla. His most important work was "Eléments de botanique ou méthode pour connaître les plantes" (1694; three volumes with 451 plates). Ho also compiled a materia medica, which was published in French after his death, an English translation appearing in 1708. A tremendous worker and a vivacious, gay and charming personality, de Tournefort died on November 28, 1708, at the age of fifty-two.

\section{Nature Conservancy}

The Committee of Privy Council for Nature Conservation has appointed the following as members of the Nature Conservancy: Lord de Ramsey, Colonel J. C. Wynne Finch, Sir Graham Sutton (director of the Meteorological Office) and Prof. A. R. Clapham (professor of botany in the University of Sheffield). The vacancies have arisen through the death of Sir Arthur Tansley, and the retirement of Prof. R. Alun Roberts, Prof. R. C. McLean and of Mr. C. S. Elton, who remains a member of the Scientific Policy Committee. The following members have been reappointed for a further term of service : Lord Strang, Lord Hurcomb and Dr. E. B. Ford.

\section{Technology as an Educational Discipline}

THe presidential address to the Institution of Mining and Technology, given on May 17 by Prof. C. W. Dannatt, professor of metallurgy in the Imperial College of Science and Technology, London, was concerned with the study of technology as a branch of education. Discussing how education is acquired, he pointed out that the study of history and the study of science have much in common, following almost identical rules which should engender habits of high moral and intellectual worth : patient and persistent industry ; an honest receptivity which accepts substantiated facts even when counter to preconceived beliefs ; freedom from prejudice, and a willingness to abandon the most cherished thoughts and theories in the face of evidence; self-reliance and a readiness to challenge statements that seem open to doubt; and clarity of thought combined with constant and painstaking practice in logical inference and deduction. If these qualities become so ingrained in the mind that they are applied in every circumstance of life, the scholar, no matter what his subject of study, will be a cultured man. Accordingly, the failings of the over-specialized 